\section{International consortium to tackle cancer genomes}

Research organizations from ten countries are forming an umbrella group to generate a comprehensive catalogue of genetic mutations in up to 50 types of cancer over the next ten years.

The International Cancer Genome Consortium was announced on 29 April. It will be coordinated by a secretariat at the Ontario Institute for Cancer Research in Toronto and will include the UK Wellcome Trust, France's National Cancer Institute, Japan's RIKEN and National Cancer Center and the US National Institutes of Health (NIH). Each participant is expected to spend some US\$20 million analysing genomic change in at least one type or subtype of cancer in roughly 500 patient samples. The project aims to avoid duplication and waste by coordinating the cancer types studied and by establishing common standards of data collection and analysis.

The NIH contribution will be made by the ongoing Cancer Genome Atlas project, an ambitious effort in its pilot phase aiming to analyse genes from some 50 types of cancer. The consortium is inviting other founding countries to join by 1 September.

\section{A lift for Europe's satellites}

Galileo, Europe's planned satellite navigation system, is closer to reality following the launch of the long-delayed second verification satellite, Galileo In-Orbit Validation Element (GIOVE-B). The satellite was lofted into space from Baikonur, Kazakhstan, on 26 April, carrying an ultra-accurate atomic clock identical to those that will be used on the 30 planned operational Galileo satellites, set to be fully deployed by the end of 2013.

During the mission, GIOVE-B

will discover what the

environment is like at the altitude chosen for Galileo, and will send back signals like those intended to be used by the operational Galileo system. The launch came days after the European Parliament voted to provide the $€ 3.4$ billion (US $\$ 5.3$ billion) needed to fund Galileo after a number of commercial partners pulled out of the project last year.

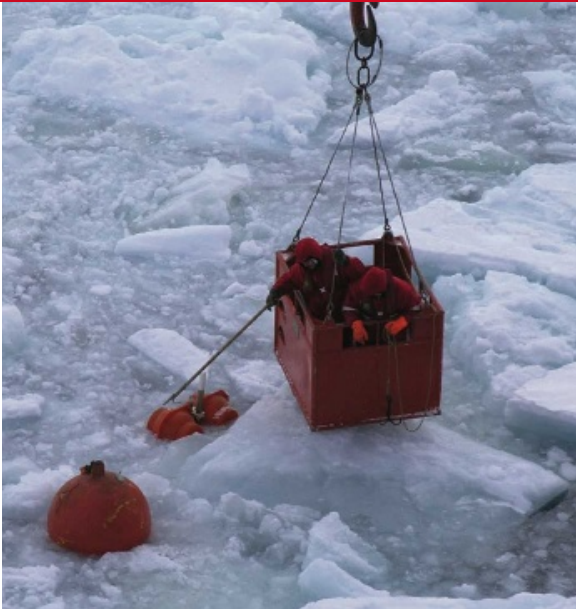

Researchers on Polarstern recover a mooring.

\section{Warming Antarctic waters begin to cool}

Antarctica's deep ocean waters are getting colder after years of warming, say researchers who have just returned from a Southern Ocean voyage aboard the German research vessel Polarstern.

Samples from previous expeditions showed that water at a depth of 4,500 metres in the Weddell Sea warmed by a tenth of a degree Celsius between 1989 and 2005 , although the warming trend may have begun earlier. The latest work, by researchers from the Alfred Wegener Institute for Polar and Marine Research in Bremerhaven, found that temperatures have cooled slightly since 2005 , suggesting that more cold surface water is reaching the deep ocean, perhaps as a result of changes in seaice coverage and atmospheric conditions. The team plans to revisit the region during the summer of 2010-11.

\section{UK government slammed for underfunding research}

An influential committee of UK politicians has accused the government of failing to provide an adequate level of funding to sustain the country's science research.

Although the overall science budget is set to increase by $17.5 \%$ by 2011 , changes within the structure mean that the actual amount of funded research will decline, charges the report from the cross-party House of Commons science select committee. That's because the budget will also need to pay for new bodies, such as the Technology Strategy Board, as well as the full economic costs of research. "We are concerned that the government has failed to protect both the existing and planned research base," says the report.

The report also has harsh words for the Science and Technology Facilities Council, which distributes research funding for physics. It says that the formation of the council in 2007 from the merger of two previous councils was "untimely and poorly conceived", and that there are weaknesses in the council's peer-review system and management. The committee concludes that "substantial and urgent changes" are needed.

\section{Creationists fail in bid to offer 'science' degrees}

A religious group has had its application to offer Master of Science degrees rejected by Texas authorities.

The Institute for Creation Research - which backs a literal interpretation of the Bible, including the creation of Earth in six days - was seeking a certificate to grant online degrees in science education in Texas (see Nature 451, 1030; 2008). But the Texas Higher Education Coordinating Board voted unanimously last week not to grant the institute's request, following the recommendation of Raymund Paredes, the state's commissioner of higher education.

"Religious belief is not science," Paredes said in his recommendation. "Science and religious belief are surely reconcilable, but they are not the same thing."

The institute has 45 days to appeal or 180 days to reapply.

\section{Artist cleared over possession of bacteria}

A US district court in Buffalo, New York, last week cleared Steven Kurtz, an art professor at the State University of New York at Buffalo, of criminal charges related to the possession of bacterial cultures.

Four years ago, Kurtz found his wife dead at their home from a heart attack, and police responding to his emergency call discovered lab equipment and cultures there. Kurtz used biological materials to create politically charged art on topics such as government policy on genetically modified crops.

Initially investigated on charges of bioterrorism (see Nature 429, 690; 2004), Kurtz was indicted in 2004 for mail and wire fraud after receiving bacterial samples through the post. The case inspired the 2007 film Strange Culture.

In February, Robert Ferrell, a researcher at the University of Pittsburgh in Pennsylvania who sent the samples to Kurtz, pleaded guilty to mailing an injurious article and was fined $\$ 500$.

\footnotetext{
Correction

The News story 'Data show extent of sexism in physics' (Nature 452, 918; 2008) incorrectly stated the percentage of talks given by female physicists on the DZero collaboration. Between May 2007 and May 2008, women gave $15 \%$ of all talks by the group.
} 